Jurnal Health Sains: p-ISSN : 2723-4339 e-ISSN : 2548-1398

Vol. 2, No. 2, Februari 2021

\title{
PENGALAMAN KELUARGA MERAWAT PASIEN KANKER DI KOTA TANJUNG
}

\section{Ahmad Rizqie Kurniawan, Bahrul Ilmi dan Hiryadi}

Universitas Muhammadiyah Banjarmasin, Poltekes Kemenkes Banjarmasin dan Universitas Muhammadiyah Banjarmasin

Email: rizqiekurniawan@gmail.com, ilmie.bahrul@gmail.com dan Hiryadi_mb@yahoo.com

\begin{tabular}{ll}
\hline ARTIKEL INFO & ABSTRACT \\
\hline Tanggal diterima: 5 Februari & Cancer is a complex group of diseases with various \\
2021 & manifestations, depending on which body system is affected \\
Tanggal revisi: 15 Februari & and the type of tumor cells involved. Cancer can affect \\
2021 & people of any age, gender, ethnicity or geographic area. The \\
Tanggal yang diterima: 25 & fact in the field that cancer has a significant negative impact \\
Februari 2021 & on physical, psychosocial activity such as anxiety, fear, \\
\hline Keywords: & sadness, depression and financial problems is related to the \\
Cancer; family; caring & cost of treatment, which is a result of cancer symptoms from \\
experience & before and after treatment. There fore cancer sufferers need \\
& help from others, one of the closest people is family. This \\
& study aims to explore the experiences of families who have \\
& treated cancer patients in the city of Tanjung. Qualitative \\
& data were obtained through in-depth interviews with 5 family \\
& members who had treated cancer patients at home. The \\
& results of the study found 8 main theme namely Wound care, \\
& Palliative care: physical aspects (less physical complaints), \\
& Family efforts in seeking treatment, Fulfill the client's basic \\
& needs, Keep quality of life, Family response in performing \\
& client care, Decisions on implementing client care at home \\
and Benefits to families in caring for clients with cancer. The & results of this study concluded that the importance of the role \\
of the family in caring for cancer patients in fulfilling their & daily needs, assistance provided by the family and family \\
support in order to improve the quality of life for clients and & families have various responses during treatment such as \\
positive responses and negative responses. Likewise, the & family also gets benefits after doing care for the client itself \\
and for the family itself.
\end{tabular}

Kata Kunci:

Kanker; keluarga; pengalaman merawat

\begin{abstract}
ABSTRAK
Penelitian ini bertujuan mengekplorasi pengalaman keluarga yang pernah merawat pasien kanker di kota Tanjung. Data kualitatif diperoleh melalui wawancara mendalam pada 5 anggota keluarga yang pernah merawat pasien kanker di rumah. Hasil penelitian menemukan 8 tema utama yaitu Perawatan luka, Perawatan paliatif: aspek fisik (keluhan fisik berkurang), Upaya keluarga dalam pencarian pengobatan, Menjaga kualitas hidup klien, Pemenuhan kebutuhan dasar klien, Respon keluarga dalam melakukan perawatan klien, Keputusan pelaksanaan perawatan klien di rumah dan
\end{abstract}


Manfaat bagi keluarga dalam merawat klien dengan kanker. Hasil penelitian ini menyimpulkan bahwa pentingnya peran keluarga dalam merawat pasien kanker dalam hal pemenuhan kebutuhan sehari-hari, pendampingan yang dilakukan keluarga dan dukungan keluarga agar meningkatkan kualitas hidup klien serta keluarga memilik respon yang bervariasi selama melakukan perawatan seperti respon positif dan respon negatif. Demikian keluarga juga mendapatkan manfaat setelah melakukan perawatan bagi klien itu sendiri maupun bagi keluarga itu sendiri.

Coresponden Author:

Email: rizqiekurniawan@gmail.com Artikel dengan akses terbuka dibawah lisensi

\section{Pendahuluan}

International Agency for Research on Cancer (IARC), menyatakan kejadian kanker pada tahun 2012 sebanyak 14,1 juta kasus baru dengan mortalitas sebanyak 8,2 juta kasus, dan kejadian ini meningkat pada tahun 2018 menjadi 18,1 juta kasus baru disertai dengan peningkatan mortalitas sebanyak 9,6 juta kasus dimana kanker paru, payudara dan colorectum merupakan 3 jenis kanker terbanyak. Dalam hal ini Indonesia mengalami peningkatan menurut Riset Kesehatan Dasar pada tahun 2018, kejadian kanker secara umum mengalami peningkatan mulai pada tahun 2013 yaitu mencapai 1,4/1000 sampai pada tahun 2018 secara signifikan meningkat menjadi 1,8/1000. Kemkes dalam artikel "Hari Kanker Sedunia 2019" menjelaskan bahwa angka kejadian penyakit kanker di Indonesia 136,2/100.000 penduduk berada pada urutan 8 di Asia Tenggara, sedangkan di Asia urutan ke-23. Peningkatan kejadian ini juga terjadi di Kalimantan Selatan dimana pada tahun 2013 penderita kanker sebanyak 1,6/1000 penduduk dan meningkat menjadi 2,13/1000 penduduk pada tahun 2018.

Kanker adalah sekelompok penyakit kompleks dengan berbagai manifestasi, bergantung pada sistem tubuh mana yang terpengaruh dan jenis sel tumor yang terlibat. Kanker dapat menyerang orang dari segala usia, jenis kelamin, etnis atau wilayah geografis. Meskipun insiden dan angka kematian kanker terus menurun sejak tahun 1990, penyakit ini tetap menjadi salah satu penyakit yang paling ditakuti. Ketakutan yang ditimbulkan oleh bahkan saran diagnosis kanker sering menimbulkan perasaan putus asa dan tidak berdaya (Galway et al., 2012).

Fakta di lapangan bahwa kanker menimbulkan dampak yang lebih kompleks kepada penderita kanker. Dalam hal ini penderita kanker memiliki dampak negative yang signifikan terhadap aktivitas fisik serta secara psikososial seorang penderita kanker akan mempunyai rasa cemas, takut, sedih, depresi serta masalah finansial berkaitan dengan biaya perawatan, yang mana akibat dari gejala kanker dari sebelum dan sesudah menjalani pengobatan, maka dari itu penderita kanker membutuhkan bantuan orang lain salah satunya orang yang paling terdekat adalah keluarga. Pada situasi demikian pasien membutuhkan dukungan dari dokter, perawat, para survivor cancer dan orang-orang terdekat terutama keluarga (Anggraeni \& Indrarti, 2012).

Orang yang paling bertanggung jawab dalam perawatan pasien penderita kanker 
adalah keluarganya sendiri atau disebut dengan family caregiver. Family caregiver pada pasien kanker adalah individu yang bertugas sebagai perpanjangan peran dari tenaga profesional yang memberikan perawatan dan bantuan secara sukarela terkait kondisi kesehatan kepada anggota keluarga yang menderita kanker. (Setiawan, 2019) didalam penelitiannya bahwa family care giver penting untuk kesejahteraan pasien kanker stadium lanjut selama penyakit pasien bergantung kepada family caregiver untuk dukungan emosional, finansial, dan material; transportasi ke rumah sakit, perawatan medis serta bantuan dengan aktivitas kehidupan sehari-hari, termasuk memakai pakaian dan makan.

Keluarga adalah unit terkecil dalam masyarakat. salah satu fungsi keluarga adalah memberikan pelayanan kesehatan, dan pelayanan kesehatan yang merupakan unit utama dalam pencegahan dan pengobatan penyakit. Serat partisipasi dan dukungan keluarga akan mendukung proses pemulihan. (Brewin, 2013) menunjukkan bahwa dukungan keluarga adalah proses seumur hidup. Keluarga memegang peranan yang sangat penting sebagai caregiver dalam pengobatan pasien kanker, terutama dalam menunjang motivasi pasien untuk menerima pengobatan. Menurut penelitian (Henriksson \& Årestedt, 2013) pasien kanker yang mendapat dukungan keluarga akan meningkatkan kualitas hidupnya. Keluarga juga berdampak pada berbagai pengobatan dan perawatan. Orang yang didukung oleh anggota keluarga akan merasa diperhatikan, dicintai, berharga, dapat berbagi beban, memiliki kepercayaan diri dan membangun harapan untuk menghindari atau mengurangi stres.

Pada keluarga dengan kanker stadium lanjut diharapkan bisa menerapkan koping yang positif dalam penanganan masalah mereka baik masalah fisik maupun masalah psikososial. Penggunaan koping yang positif dapat meningkatkan kemampuan keluarga dalam perawatan pasien dan bagi keluarga sendiri juga terhindar dari efek negatif dari masalah-masalah fisik dan psikologis yang timbul selama merawat anggota keluarga (Huda et al., 2019). Dalam penelitian (Dwijayanti \& Rifa'i, 2015) menyatakan bahwa erat kaitannya keluarga yang merawat pasien kanker dengan memberikan kebutuhan biologis, psikologis, sosial dan spiritual. Family caregiver yang merawat penderita kanker, merupakan sumber daya kunci untuk kesejahteraan pasien dengan bantuan dan keterlibatan aktif mereka dalam keputusan pengobatan dan perencanaan perawatan. Dalam proses penyakit yang tidak dapat disembuhkan (Ullrich \& Nitsche, 2020)

Inti dari perawatan yang dilakukan oleh keluarga ada kaitannya dengan teori keperawatan Virginia Henderson dalam (Alligood, 2014) yang mana keluarga sebagai Family caregiver yang mana tugasnya membantu kebutuhan-kebutuhan dasar penderita kanker maka dari itu 14 kebutuhan dasar Virginia Henderson tersebut mencakup fisiologis, psikologis, spiritual dan sosial, setiap komponen jelas dan tidak perlu dijabarkan sehingga mudah untuk mencapai tujuan yang dipilih, dapat diaplikasikan pada semua umur dan perkembangan manusia. Pada pasien kanker stadium lanjut memiliki masalah yang kompleks dapat mempengaruhi sistem organ secara keseluruhan, pemilihan 14 kebutuhan dasar dari Virginia Henderson kebutuhan pasien dapat terkaji secara lebih spesifik karena terangkum dalam kebutuhan fisiologis yang holistik, psikogis, sosial dan spiritual (Rodriguez-Mateos et al., 2019).

\section{Metode Penelitian}

Penelitian ini menggunakan metode penelitian kualitatif dengan pendekatan fenomenologi, yang bertujuan untuk 
mengidentifikasi dan mengeksplorasi pengalaman keluarga merawat pasien kanker di rumah. Ada lima partisipan yang terlibat pada penelitian ini. Lima partisipan ini adalah keluarga yang pernah merawat pasien kanker serta keluarga yang bersedia menceritakan pengalamannya merawat pasien kanker.

\section{Hasil dan Pembahasan}

Karakteristik partisipan (responden) meliputi Partisipan laki-laki sebanyak 3 orang dan partisipan perempuan 2 orang. Usia partisipan bervariasi dengan usia termuda 27 tahun dan tertua 64 tahun. Pekerjaan partisipan bermacam-macam seperti karyawan swasta, PNS, apoteker serta ibu rumah tangga. Latar belakang pendidikan partisipan yaitu sarjana strata 1 sebanyak 4 orang serta SMA sebanyak 1 orang. Semua partisipan berstatus telah menikah. Hubungan klien dengan anggota keluarga bermacammacam yaitu suami, adik ipar serta anak.

Hasil penelitian mengeksplor pengalaman keluarga yang pernah merawat pasien kanker di rumah sebanyak 9 tema sebagai berikut:

\section{Perawatan luka}

a. Membantu dressing luka

Hasil dari tema yang didapatkan adalah bagaimana keluarga melakukan perawatan luka terhadap pasien kanker dikarenakan terdapat darah dan nanah di lokasi payudara klien yang mana keluarga mengatakan bahwa pentingnya perawatan luka pada klien yang bertujuan mengurangi risiko infeksi pada area luka tersebut maka dari itu keluarga berpartisipasi dalam pelaksanaan membantu dressing luka.

Kanker payudara ialah sebuah penyakit yang timbul karena terdapat gangguan dipertumbuhan sel di dalam jaringan payudara, sehingga mengakibatkan payudara menjadi bengkak dan terdapat luka nanah serta darah di dalamnya (Aini, 2016). Sejalan dengan (Gitarja, 2017) menjelaskan bahwa luka kanker dikenal pula dengan sebutan fungating malignant wound atau malignant cutaneous wound.

Maka dari itu berdasarkan pemaparan diatas bahwa luka pada pasien kanker payudara dapat mengakibatkan bengkak dan sering kali terdapat luka dan nanah demikan salah satu penanganan agar luka tersebut tetap terjaga kebersihannya maka diperlukan perawatan luka Sejalan dengan salah satu fungsi keluarga menurut Friedman yaitu fungsi perawatan kesehatan dimana keluarga menyediakan perawatan kesehatan bagi klien salah satunya melaksanakan perawatan luka yang dilakukan oleh perawat dan keluarga, penting bagi keluarga dalam melakukan perawatan luka agar menjaga kebersihan luka yang diderita klien.

b. Mengganti perban

Keluarga membantu perawat dalam melakukan perawatan luka yaitu mengganti perban yang bertujuan agar kebersihan luka terjaga, karena menurut (Mu'afiro et al., 2019) ketika luka di perban maka akan menyebabkan luka lembab dan luka akan bertambah lama untuk sembuh. Perban adalah salah satu perlengkapan medis pendukung keperawatan yang biasa digunakan untuk membalut luka.

Berdasarkan penjelasan diatas pentingnya keluarga mengganti perban karena perban memilik fungsi yang beragam memperngaruhi dalam proses penyembuhan luka kanker karena penerapan perban yang salah juga dapat mengakibatkan kerusakan jaringan serta lokasi luka dapat mempengaruhi bagaimana jenis luka tersebut sehingga dianjurkan sebelum 
mengganti perban dilakukan perawatan luka.

c. Perawatan luka secara intensif

Perawat melakukan perawatan luka kanker secara terjadwal sejalan dengan penelitian (Mu'afiro et al., 2019) menjelaskan bahwa peran tenaga kesehatan dalam mengatasi luka kanker, khususnya perawat mempunyai peran penting menggunakan pengetahuan dan keterampilannya, salah satunya peran preventif untuk merawat luka kanker agar luka selalu bersih, dan terhindar dari infeksi. Serta memberikan peran kuratif dalam merawat serta mengobati luka kanker tersebut agar luka dapat segera sembuh.

Berdasarkan pemaparan dari 3 (tiga) kategori tersebut seperti yang diungkapkan oleh partisipan bahwa penting menjaga kebersihan luka pasien kanker dengan tindakan perawatan luka yang dilakukan oleh perawat secara intensif sejalan dengan teori keperawatan Virginia henderson perawatan luka termasuk dalam pemenuhan kebutuhan personal hygiene dimana dijelaskan oleh (Perry \& Potter, 2016) dalam buku karangan bahwa perawatan kulit mencakup pada kebersihan kulit, kulit memiliki fungsi mengeliminasi sel mati, mensintesis sel baru dan sebagai mediator pertukaran oksigen, cairan dan nutrisi dengan pembuluh darah yang ada dibawahnya.

Sejalan dengan (Raisch et al., 2012) tugas seorang caregiver salah satunya adalah melakukan dukungan medis yang termasuk manajemen luka dalam hal ini keluarga berpartisipasi juga dalam pelaksanaan perawatan luka bersama perawat dengan demikian keluarga memiliki tugas di bidang kesehatan yaitu merawat keluarga yang memiliki gangguan kesehatan.

\section{Perawatan paliatif : Aspek fisik (Keluhan fisik berkurang)}

Hasil penelitian ini didapat 1 (satu) sub tema yaitu metode untuk mengatasi keluhan, menunjukan bahwa keluarga mengatasi keluhan klien seperti nyeri yang mana ada kaitannya dengan perawatan paliatif yang meliputi penatalaksanaan nyeri Metode pereda nyeri nonfarmakologis merupakan tindakan mandiri perawat untuk mengurangi intensitas nyeri sampai dengan tingkat yang dapat ditoleransi oleh pasien (Perry \& Potter, 2006). Menurut (Koloski et al., 2012) bahwa seorang caregiver keluarga dalam perawatan paliatif didefinisiskan sebagai sanak saudara, teman ataupun pasangan yang ikut terlibat dalam perawatan pasien dam biasanya mempersiapkan fisik, praktik dan emosi juga dukungan tanpa dibayar. Berdasarkan dengan pengertian perawatan paliatif merupakan pelayanan kesehatan yang bersifat holistik dengan melibatkan berbagai profesi.Implementasi perawatan paliatif yang harus diterapkan di rumah sakit meliputi penatalaksanaan nyeri, penatalaksanaan keluhan fisik, pemberian dukungan psikologis, sosial, dan spiritual (Larsen et al., 2017) dalam (Janitra et al., 2019). terdapat 2 (dua) metode yang dilakukan keluarga dalam mengatasi keluhan nyeri yaitu :

Manajemen nyeri non-farmakologis

a. Manajemen nyeri non-farmakologis : Distraksi sentuhan (Massage/Pijat)

Kategori pertama yang membentuk sub tema ini yaitu bahwa keluarga melakukan manajemen nyeri non-farmakologis yaitu dengan distraksi sentuhan (Massage/pijat) dalam mengurangi nyeri klien. 
Nyeri merupakan gejala yang paling sering pada klien dengan perawatan paliatif. Nyeri pada klien paliatif tidak hanya respon fisik terhadap gangguan atau penyakit yang mendasarinya, namun akibat dari berbagai dimensi emosional intelektual, perilaku, sensori, dan juga budaya klien (Black \& Hawks, 2014).

Teknik untuk melakukan hand massage dapat dilakukan dengan beberapa pendekatan, salah satu metode dilakukan adalah dengan memberikan tekanan lembut dan gesekan di seluruh telapak tangan klien dengan melibatkan gerakan melingkar kecil dengan menggunakan ujung jari atau ibu jari perawat dalam waktu 510 menit (Kolcaba et al., 2014). Upaya sentuhan yang lembut dapat memberikan kesenangan dan kenyamanan bagi pasien teknik ini bisa dilakukan oleh keluarga secara mandiri dalam mengatasi nyeri klien.

b. Manajemen nyeri non-farmakologis: Relaksasi (Tarik napas dalam)

Kategori kedua yang membentuk sub tema ini yaitu bahwa keluarga melakukan manajajemen nyeri non-farmakologis yaitu dengan relaksasi (tarik napas dalam) dalam hal ini pasien kanker memiliki efek nyeri akibat penyakitnya sebagaimana seperti yang dipaparkan oleh (Sumiati, 2017) nyeri adalah perasaan tidak nyaman dan pengalaman emosi yang berhubungan dengan atau telah rusaknya jaringan. Nyeri merupakan hal yang sangat kompelks, dengan gejala multidimensi yang ditentukan tidak saja oleh kerusakan jaringan dan nosiseptif, tatapi juga oleh aspek kepercayaan seseorang, pengalaman nyeri, kondisi psikis, motivasi, serta lingkungan sekitarnya.
Berdasarkan penjelasan di atas bahwa dalam perawatan keluarga terhadap pasien kanker di rumah, secara tidak langsung keluarga melakukan manajemen nyeri nonfarmakologis dengan cara distraksi sentuhan (pijat) dan teknik relaksasi (tarik napas dalam) sejalan dengan tindakan perawatan paliatif terhadap pasien kanker bahwa nyeri merupakan salah satu masalah yang sering terjadi pada pasien kanker dengan keadaan paliatif sesuai dengan indikator tercapainya tujuan perawatan paliatif menurut Direktorat Bina Pelayanan Keperawatan Dan Keteknisian Medis Kementerian Kesehatan (2012) yaitu aspek fisik berkurang (keluhan fisik berkurang.

\section{Upaya keluarga dalam pencarian pengobatan}

a. Membawa klien ke fasyankes (Puskesmas dan rumah sakit)

Keluarga membawa klien ke puskesmas dan rumah sakit Kategori pertama yang membentuk sub tema ini yaitu bagaimana keluarga membawa klien ke puskesmas dan ke rumah sakit yang mana keluarga berpartisipasi dalam dukungan pengobatan, pemeriksaan lab untuk klien di puskesmas dan rumah sakit serta mencari informasi tentang bagaimana pengobatan kanker tersebut.

Dalam hal ini peran keluarga sebagai orang terdekat terhadap penderita kanker sama halnya dengan tugas seorang caregiver informal yaitu seperti yang dijelaskan oleh (Raisch et al., 2012) yaitu tugas seorang caregiver ialah memberikan dukungan medis salah satunya membantu dalam pengobatan, sejalan dengan (Pegado et al., 2016) menjelaskan bahwa fungsi dari caregiver keluarga adalah merawat 
klien yang menderita suatu penyakit termasuk salah satunya membawa klien ke pelayanan kesehatan.

b. Keluarga mengambil keputusan untuk pengobatan di rumah sakit

a) Keluarga mempunyai tugas dalam pemberi keputusan dalam pengobatan klien dengan kanker. Keputusan menurut (Knaul et al., 2016) menjelaskan adalah ketegasan terhadap solusi dan keputusan akan jawaban pertanyaan dari masalah yang dihadapinya atau pilihan pada suatu alternatif sebagai suatu pengakhiran yang harus dilakukan untuk mengatasi masalah dan merupakan proses jawaban pertanyaan terhadap masalah yang dihadapi.

Tugas keluarga dalam bidang kesehatan menurut (Friedman et al., 2010) bahwa dalam mengambil keputusan untuk melakukan tindakan kesehatan yang tepat bagi keluarga. Tugas ini merupakan upaya keluarga yang utama untuk mencari pertolongan yang tepat sesuai dengan keadaan keluarga, dengan pertimbangan siapa diantara keluarga yang mempunyai kemampuan memutuskan untuk menentukan tindakan keluarga. Tindakan kesehatan yang dilakukan oleh keluarga diharapkan tepat agar masalah kesehatan dapat dikurangi atau bahkan teratasi.

b) Kecukupan dana perawatan

Peran keluarga dalam
pengambil keputusan dalam
pengobatan klien tidak luput dari
dukungan finansial yang mencakup
dari kecukupan dana perawatan
seperti memiliki asuransi kesehatan.
Hal ini dilihat dari dukungan

anggota keluarga untuk menyediakan finansial untuk pengobatan pasien. Penyediaan finiansial ini dilakukan keluarga dengan cara tetap bersemangat untuk bekerja serta menggunakan bantuan asuransi kesehatan dari pemerintah.

Dalam hal dukungan finansial dari keluarga yang menjadi caregiver sejalan dengan teori yang dipaparkan oleh (Raisch et al., 2012) salah satu tugas spesifik dari seorang caregiver ialah memiliki tugas pengaturan jaminan dan keuangan (insurance and financial) yaitu menyeleksi rencana asuransi yang tepat, membantu menyiapkan obat baru dan obatobatan yang mahal, atau menemukan sumber asuransi dan menyelamatkan keuangan.

c. Menggunakan pengobatan alternatif Selama proses pengobatan medis yang dilakukan klien keluarga juga mengungkapkan bahwa mereka yakin menggunakan obat tradisional. Sebagaimana asumsi peneliti bahwa masih banyak orang-orang yang sakit menggunakan pengobatan tradisional di karenakan mungkin biaya pengobatan yang mahal dan kondisi yang sulit disembuhkan.

Sebagaimana penelitian sebelumnya yang dilakukan oleh (Aviyah \& Farid, 2014) bahwa pada populasi kanker payudara di Malaysia menunjukkan bahwa alasan mereka berobat ke pengobatan tradisional adalah (1) rekomendasi dari teman dan keluarga, (2) sanksi dari keluarga, (3) manfaat dan kesesuaian yang dirasakan, (4) kredibilitas terapis 
pengobatan tradisional dan (5) keberatan dengan sistem medis Barat dan penundaan sistematis.

Bisa kita simpulkan dari beberapa penelitian yang mendukung tema ini bahwa keluarga atau orang terdekat masih mempengaruhi klien yang menderita kanker untuk melakukan pengobatan tradisional.

\section{Menjaga kualitas hidup klien}

Berdasarkan hasil penelitian ini bahwa dalam menjaga kualitas hidup klien keluarga selalu selalu berusaha memberikan pelayanan yang terbaik dalam menjaga kualitas hidup klien dengan cara mempertahankan keadaan kesehatan klien, mendoakan klien, berusaha memenuhi keinginan klien dan memandirikan agar klien berharga serta keluarga membantu dalam proses menuju kemandirian klien dengan cara selalu mendampingi, memenuhi kebutuhan klien dengan demikian klien terjaga kualitas hidupnya.

a. Peningkatan kualitas hidup

a) Berusaha memberikan pelayanan terbaik

Keluarga sebagai suatu kelompok individu yang tinggal bersama dan saling ketergantungan mempunyai peran utama dalam pemeliharaan kesehatan seluruh anggota keluarga dan bukan individu itu sendiri yang mengusahakan tercapainya kesehatan yang diinginkan (Sudiharto, 2017). Dalam hal ini penderita kanker memiliki masalah dalam dirinya termasuk dari kondisi fisik dan psikologis yang berakibat menurunnya kualitas hidup.

Sejalan dengan penjelasan (Saxton \& Daley, 2011) Penderita kanker payudara banyak mengalami perubahan dalam dirinya dan kehidupan sehari-harinya, yang meliputi kondisi fisik dan psikologis seperti nyeri, kelelahan, istirahat tidur sedangkan psikologis seperti penampilan, konsep diri, perasaan positif dan perasaan negatif. Hal tersebut berlangsung sejak proses diagnosis hingga akhir hidupnya berfokus pada kesehatan, kehidupan penderita kanker dan pada saat menjalani pengobatan.

Penderita kanker payudara membutuhkan terapi dan pengobatan, sedangkan terapi maupun pengobatan untuk kanker payudara itu sendiri akan menimbulkan dampak baik positif maupun negatif. Masalah yang dialami penderita kanker payudara jangka panjang akan mempengaruhi kualitas hidup (Ongge, 2015).

Individu yang memiliki kualitas hidup yang baik akan memiliki kesehatan jasmani dan rohani yang baik, serta dapat menjalankan hidup di dalam masyarakat sesuai perannya masing-masing. Kualitas kehidupan dapat membantu menentukan masalah tertentu yang mungkin muncul pada penderita (Noviarini et al., 2013).

b) Proses menuju kemandirian klien

Kategori ini membentuk sub tema bagaimana keluarga dalam meningkatkan kualitas hidup dari segi membantu aktivitas serta mendampingi dalam pemenuhan aktivitas sehari-hari. Menurut (Friedman et al., 2010) Dukungan keluarga adalah suatu proses hubungan berupa sikap, tindakan, dan penerimaan keluarga terhadap anggotanya yang bersifat 
mendukung dan memberikan pertolongan kepada anggotanya.

Pentingnya dukungan

keluarga terhadap pemenuhan

kebutuhan aktivitas klien dengan

kanker karena mampu

meningkatkan motivasi serta

semangat hidup klien dalam

melakukan aktivitas sehari-hari

sejalan dengan (Roberts et al., 2012)

mengungkapkan bahwa. Dukungan

keluarga merupakan faktor yang sangat penting untuk memotivasi dan meningkatkan semangat hidup penderita kanker.

Berdasarkan penelitian terkait sebelumnya yang dilakukan oleh (Caesandri \& Adiningsih, 2015) meskipun tidak menjelaskan secara spesifik tentang pendampingan keluarga dalam pemenuhan kebutuhan sehari-hari peneliti menjelaskan peranan dukungan pendampingan dan kebiasaan makan pasien kanker selama menjalani terapi didapatkan hasil bahwa Peranan dukungan dikatakan baik jika pendamping memenuhi kebutuhan pasien kanker, terutama dalam hal perawatan makan dan pemenuhan nutrisi pasien. Pasien memaparkan bahwa pendamping selalu menanyakan dan memberikan makanan yang diinginkan oleh pasien agar pasien mau makan (Caesandri \& Adiningsih, 2015).

c) Memandirikan klien agar lebih berharga

Berdasarkan hasil pernyataan keluarga didapatkan bahwa dalam menjaga kualitas hidup klien maka perlunya memandirikan klien agar klien merasa dirinya berharga sehingga kualitas hidupnya terjaga.
Kualitas hidup merupakan istilah yang sering kali digunakan untuk menyatakan status kesehatan seseorang, status fungsional fisik, kemampuan menyesuaikan diri terhadap kondisi psikososial dan gejala yang muncul, kondisi sehat sejahtera, kenyamanan dalam hidup atau kebahagiaan (Barofsky, 2012). World Health Organization (WHO, 2014) dalam Boby (2019) menyatakan kualitas hidup merupakan persepsi dari individu yang menunjukkan kemampuan seseorang untuk melakukan bermacam- macam peran kepuasan dalam melakukan sesuatu sesuai konteks budaya.

Biasanya pada Pengobatan kanker memberi dampak negatif pada fisik dan mental, serta mempunyai pengaruh yang besar terhadap konsep diri. Jika konsep diri terganggu, maka berpengaruh terhadap pikiran dan tingkah laku seseorang, antara lain: kesedihan, kekhawatiran dan ketakutan akan masa depan dan kematian. Kondisi ini mempengaruhi kualitas hidup penderita kanker. Kualitas hidup penderita kanker dipengaruhi pemahaman individu terhadap penyakitnya, sehingga penderita tahu cara menjaga kesehatan (CaoLormeau et al., 2016) Seseorang yang mendapatkan dukungan keluarga dan dukungan sosial merasa diperhatikan, disayangi, merasa berharga dapat berbagi beban, percaya diri dan menumbuhkan harapan sehingga mampu menangkal atau mengurangi stres (Watson et al., 2017). 


\section{Pemenuhan kebutuhan dasar klien}

a. Pemenuhan kebutuhan personal hygiene

Beberapa partisipan mengatakan bahwa dalam memenuhi kebutuhan kebersihan diri klien salah satunya aktivitas mandi, keluarga masih membantu memandikan klien serta ada juga partisipan yang mengatakan bahwa dalam pemenuhan kebutuhan personal hygiene masih ada yang melakuakan secara mandiri yang mana sesuai dengan teori klasifikasi tingkat ketergantungan klien masuk dari kategori partial care dan minimal care.

Penelitian (Purnawan et al., 2014) mengatakan bahwa pasien kanker payudara mengalami kelemahan fisik terutama yang menjalani kemoterapi. Kelemahan, pusing, susah menggerakkan ekstremitas, dan sesak. Hal tersebut mengakibatkan pasien mengalami masalah hygiene seperti kerusakan kulit dan jaringan, kerontokan rambut, dan kurangnya perawatan diri.

Keluarga membantu pemenuhan kebutuhan personal hygiene dikarenakan kelemah fisik yang dialami klien agar kebersihan badan klien terjaga sehingga menimbulkan rasa nyaman, kesehatan dan keamanan pada klien. Sejalan dengan teori (Perry \& Potter, 2016) Perawatan kulit pada pasien kanker stadium lanjut sangat penting sebagai tindakan pencegahan luka pada kulit dan sebagai bentuk perhatian pada pasien untuk meningkatkan kesejahteraan. bentuk perawatan yang diberikan dengan memandikan pasien untuk meningkatkan kebersihan diri pasien..

b. Pemenuhan kebutuhan berpakaian

Dalam pemenuhan kebutuhan berpakaian klien mampu melakukan dengan mandiri meskipun secra perlahan tanpa bantuan keluarga yang mana tingkat ketergantungan klien masuk kategori minimal care. Cara berpakaian yang sesuai kondisi dan keadaan juga membantu peningkatan kesehatan, bagi setiap individu. Cara berpakaian yang di kenakan untuk melindungi diri dari cuaca yang panas hingga dingin agar tidak mempengaruhi tubuh.

Dalam hal ini caregiver keluarga yang merawat pasien kanker mampu memberikan kebutuhan berpakaian sesuai dengan apa yang dipaparkan oleh (McCloskey et al., 2008) seperti memepersiapkan pakaian pasien ditempat yang bisa diakses oleh pasien, membantu pasien memasang pakaiannya jika diperlukan, memfasilitasi pasien dalam hal merias wajah jika diperlukan, menaruh pakaian yang kotor, menawarkan untuk mencuci baju, menyisir rambut pasien jika diperlukan serta memberikan semangat untuk berpakaian sendiri. Berdasarkan penjelasan di atas bahwa cara berpakaian klien mempengaruhi kondisi dan keadaan pasien agar merasa nyaman dan terlindungi sejalan dengan teori pemenuhan kebutuhan dasar virginia henderson masuk dari segi pemenuhan kebutuhan berpakaian.

c. Pemenuhan kebutuhan eliminasi

Beberapa partisipan mengungkapkan bahwa dalam pemenuhan kebutuhan eliminasi masih membutuhkan bantuan BAK dan BAB (ditempat tidur dan kamar mandi) oleh keluarga yang dikarenakan kondisi fisik klien dari segi tingkat ketergantungan klien masuk pada kategori partial care.

Pemenuhan kebutuhan eliminasi pada manusia terdiri dari dua macam kebutuhan yaitu kebutuhan eliminasi fekal dan kebutuhan eliminasi urin. 
Dalam memenuhi kebutuhan eliminasi dibutuhkan pengawasan terhadap berbagai masalah yang dapat muncul terhadap pemenuhan kebutuhan eliminasi. Beberapa masalah yang dapat mucul berhubungan dengan pemenuhan kebutuhan eliminasi antara lain konstipasi, diare, inkontinesia alvi, hemoroid, inkontinensia urin, retensi urin, infeksi saluran kemih. Beberapa gangguan pada pemenuhan kebutuhan eleminasi dapat mengganggu keseimbangan individusi.

d. Pemenuhan kebutuhan nutrisi

Dalam pemenuhan kebutuhan nutrisi partisipan mengungkapkan bahwa keluarga dalam menjaga nutrisi klien yaitu membutuhkan bantuan bantuan makan dan disuapi apabila klien tidak mampu makan sendiri, serta agar tejaga kesehatannya keluarga menjaga makanan agar tidak sembarangan makan serta membutuhkan bantuan dalam menyiapkan makanan karena klien tidak mampu menyiapkan makanannya sendiri dalam kategori ketergantungan partial care karena masih dibantu oleh keluarga meskipun masih ada partisipan yang mengungkapkan bahwa klien mampu makan secara mandiri yang termasuk pada kategori minimal care.

Nutrisi salah satu faktor penting dalam proses dan fungsi tubuh, walaupun tubuh dapat bertahan tanpa nutrisi dan memiliki waktu yang lebih lama dari cairan. Beberapa hal yang dapat dipertimbangkan dalam pemenuhan kebutuhan nutrisi yaitu gizi dan kualits hidup, keseimbangan cairan, pentingnya diet dan kondisi pencernaan. Pada pasien kanker terjadi perubahan kebiasaan makan antara lain kehilangan rasa lapar, tidak menyukai makanan, dan perubahan fisik yang menyebabkan kesulitan dalam makan, mengunyah, menelan, masalah gastrointestinal. Kanker mengalami perubahan dalam respon inflamasi kronis yang sistemik, sehingga nutrisi yang diberikan untuk memberikan respon katabolik sitokim dan eicosanoid atau regulasi metabolik seperti agen anabolik atau agen anti katabolik. Manajemen nutrisi pada pasien kanker bergantung pendekatan masing-masing individu (RodriguezMateos et al., 2019).

e. Pemenuhan kebutuhan komunikasi

Berdasarkan hasil wawancara terhadap partisipan bahwa dalam membina hubungan dengan klien agar terjaga, keluarga selalu menghadirkan keluarga agar klien merasa nyaman bahwa dengan adanya kehadiran keluarga klien merasa masih merasa bahwa dirinya tidak sendiri dikarenakan ada keluarga yang selalu menemani serta agar tejaganya komunikasi dengan klien dibutuhkan juga komunikasi yang baik dengan keluarga.

Sejalan dengan teori (Ferrell \& Coyle, 2016) Efek fisik dari kanker dan terapinya dapat menyebabkan tekanan psikologis yang serius. Pada konteks kanker tekanan ini didefinisikan sebagai pengalaman emosional yang tidak menyenangkan dan bersifat mulitifaktor. Pasien kanker stadium lanjut mengalami ketakutan dan kecemasan terkait kejadian dimasa depan yang tidak pasti, rasa sakit yang dialami terus-menerus, perpisahan dari orang yang dicintai dan kehilangan kontrol.

f. Pemenuhan kebutuhan psikologis Pemenuhan kebutuhan psikologis penderita kanker oleh 
keluarga bertujuan untuk meningkatkan kualitas hidup klien dengan cara memberikan dukungan emosional, memotivasi klien dan memberi semangat. Karena itu, peran keluarga dan orang di sekitarnya untuk memberikan dukungan hidup untuk penderita akan sangat besar artinya. Jadi, keluarga harus merawat penderita agar tidak mengalami stres dan kemudian depresi akan penyakit yang tengah dideritanya tersebut. Terdapat hubungan yang kuat antara keluarga dan status kesehatan anggotanya dimana peran keluarga sangat penting bagi setiap aspek perawatan kesehat ananggota keluarga, mulai dari strategi-strategi hingga fase rehabilitasi, serta dukungan keluarga sangat berpengaruh terhadap kesehatan mental

Sesuai dengan hasil penelitian yang dilakukan oleh (Saragih, 2018) pada pasien kanker yang menjalani kemoterapi bahwa berdasarkan dukungan emosional keluarga dalam kategori baik yaitu $52 \%$ pasien menerima dukungan emosional dari keluarga. Terdapatnya dukungan dari keluarga akan membuat pasien tidak merasa sendiri dan pasien merasa bebannya berkurang karena dapat mencurahkan segala yang dirasakannya kepada keluarga. Dukungan keberadaan yang diberikan keluarga dapat membantu partisipan terhadap penguasaan emosi yang dapat timbul saat menjalani pengobatan kemoterapi.

g. Pemenuhan kebutuhan spiritual

Beberapa bahwa $\begin{array}{r}\text { partisipan } \\ \text { dalam } \\ \text { aktivitas }\end{array}$
mengungkapkan
kemenuhan
sholat 5 (lima) waktu masih dibantu
oleh keluarga, klien selama mengidap

penyakit kanker masih mengikuti kegiatan pengajian, keluarga tidak lupa mengingatkan klien untuk berdoa kepada tuhan agar diberi kesembuhan, serta memberikan saran untuk melakukan zikir, istigfhar dan bershalawat agar klien merasa tenang.

Spiritual merupakan konsep unik yang terjadi secara pribadi pada individu yang bersifat kompleks yang dipengaruhi oleh pengalaman hidup, budaya, kepercayaan, perkembangan dan ide-ide tentang kehidupan seseorang. Spiritual memberikan individu energi yang dapat membantu mereka untuk beradaptasi pada kondisi yang sulit dan untuk memelihara kesehatan. kepercayaan (agama) merupakan hubungan individu dengan kekuatan tertinggi yang pada setiap individu mempercayai keberadaan yang beralasan keyakinan dan kepercayaan.

h. Pemenuhan kebutuhan oksigen

Beberapa partisipan mengungkapkan bahwa klien memiliki keluhan sesak napas selama menderita penyakit kanker, cara mengatasi keluhan tersebut dengan cara memberikan posisi setengah duduk dan memasangkan oksigen, Oksigen dibutuhkan untuk mempertahankan kehidupan, fisiologi pernafasan meliputi oksigenasi tumbuh melalui mekanisme ventilasi, perfusi dan transport gas pernafasan, faktor yang ikut berperan pengaturan saraf dan kimiawi dalam mengontrol frekuensi dan kedalaman pernafasan.

Sesak nafas membuat seseorang tidak nyaman dan sulit melakukan aktivitas. Keluhan ketidakefektifan pola nafas umum dirasakan pasien kanker, diperkirakan sekitar 15\% - 55\% pada saat pasien didiagnosis dam sekitar $18 \%$ - $79 \%$ pada minggu 
terakhir kehidupan pasien (Bisaro et al., 2012).

Gangguan pemenuhan oksigen pada pasien kanker terjadi pada kondisi kanker paru dan metastasis, kanker primer yang menyebabkan gangguan oksigenasi terjadi pada kanker gastrointestinal dan payudara. Keluhan sesak nafas pada kanker dipengaruhi oleh nyeri dan status fungsional. Sesak nafas merupakan salah satu gejala yang menyebabkan peningkatan distress, yang berhubungan dengan peningkatan cemas dan depresi dan mempengaruhi kualitas hidup penderita kanker (Ekström et al., 2016).

i. Pemenuhan kebutuhan gerak dan kesimbangan tubuh

Partisipan mengungkapkan bahwa dalam memberikan kebutuhan gerak dan keseimbangan tubuh klien yang mana akibat dari ketidakmampuan klien bergerak, keluarga membantu memiringkan badan klien serta membantu klien ingin duduk.

Penurunan fungsi fisik dan kelemahan sangat sering dikeluhkan oleh pasien kanker stadium lanjut hal ini dapat berhubungan dengan pengobatan kanker dan progresifitas dari penyakit. Fatique juga berkontribusi terhadap kelemahan yang dialami oleh pasien kanker stadium lanjut dimana fatique mempengaruhi aktivitas hidup, penurunan memori, kelemahan umum, emosional yang labil dan penurunan status fungsional (Albrecht \& Taylor, 2012).

Dalam pemenuhan kebutuhan gerak dan keseimbangan pada pasien kanker stadium lanjut ada beberapa hal dapat dilakukan yaitu mendorong pasien untuk beraktivitas ditempat tidur atau turun dari tempat tidur (jika memungkinkan). Latihan aktivitas dapat dilakukan dengan membantu dalam pergerakan pergelangan kaki, lutut, pinggul, tangan, siku, bahu. Latihan dilakukan berulang sampai batas kemampuan pasien. Memijat otot- otot atau persendian pasien. Mencegah terjadinya dekubitus atau luka pada kulit akibat tekanan yang lama, tindakan yang dapat dilakukan adalah membantu pasien mengubah posisi per 2 jam. Saat membantu pasien bergerak usahakan untuk tidak menyeret karena akan melukai kulit. Berdasarkan uraian diatas bahwa yang dilakukan keluarga sejalan dengan penerapan teori keperawatan Virginia Henderson yaitu mempertahankan gerak dan posisi yang diinginkan.

j. Pemenuhan kebutuhan menjaga suhu tubuh

Dalam sub tema ini ditemukan 2 (dua) kategori dalam mengatasi demam klien seperti kompres dan terapi farmakologis karena hampir semua orang dengan kanker mengalami demam terutama bila pengobatan mempengaruhi sistem kekebalan tubuh.

Demam dapat disebabkan infeksi, dan proses inflamasi, demam dapat terjadi pada pasien kanker yang disebabkan oleh infeksi, obat- obatan, tumor, trombosis atau dapat disebabkan transfusi darah. Pada individu yang mendapatkan kemoterapi lebih cenderung mengalami infeksi yang disebabkan oleh nilai leukosit yang menurun akibat depresi pada pertumbuhan sel darah.

Beberapa hal dapat dilakukan oleh keluarga untuk mempertahankan suhu dengan melepaskan atau mengurangi pakaian yang tebal atau selimut yang digunakan, berikan 
pakaian yang tipis, bila pakaian basah bisa segera diganti. Berikan suhu lingkungan yang membantu mendinginkan kulit bisa dapat dilakukan dengan memandikan pasien (Roberts et al., 2012).

k. Pemenuhan kebutuhan keamanan dan keselamatan

Keamanan merupakan kebutuhan dasar manusia yang seringkali didefinisikan suatu kondisi yang tidak mengalami cedera fisik dan psikologis. Selain itu kemanan mencakup lingkungan fisik dan psikososial yang mempengaruhi kelangsungan hidup pasien. Keamanan yang diharapkan bertujuan untuk mengurangi angka kejadian cedera, mengoptimalisasi hospitalisasi sehingga pasien dapat pulang tepat waktu, meningkatkan status fungsi pasien (Perry \& Potter, 2006).

Bahaya fisik yang dapat mengakibatkan jatuh dapat di minimalkan melalui pencahayaan yang adekuat terutama pada tempat pasien melakuakn aktivitas, pencahayaan dapat berupa cahaya yang tidak dapat menyilaukan mata, pengurangan penghalang fisik beberapa benda yang dapat menyebabkan cedera antar lain lantai yang basah, keset, lemari dan benda-benda yang dapat menghalangi pasien. Hal yang harus diperhatikan adalah barang-barang yang dibutuhkan oleh pasien sebaiknya ada dalam jangkauan.pasien, pengontrolan bahaya yang dapat terjadi di kamar mandi, dan berbagai tindakan pengamanan yang dapat digunakan.

1. Pemenuhan kebutuhan istirahat dan tidur

Istirahat memberikan rasa rileks secara mental, bebas dari rasa cemas dan tenang secara fisik. Istirahat dilakukan untuk memberikan energi baru pada aktivtas metal dan fisik individu sehingga dapat melakukan aktivitas secara optimal. Beberapa faktor yang mempengaruhi kemampuan untuk memperoleh istirahat yang cukup antara lain lingkungan, gaya hidup, konflik. Tidur merupakan proses fisiologis yang bersiklus yang bergantian dengan periode tertentu. Tidur berkontribusi dalam pemulihan fisiologis dan psikologis. Tidur seacara teratur memberi keuntungan pada poses biologis yang dipebaharui secara rutin (Perry \& Potter, 2006). Keluarga dalam mengatasi gangguan tidur klien, keluarga menyarankan teknik tidur ayam atau tidur tahap 1 NREM menurut situs hellosehat.com (2021) menjelaskan bahwa selama tahapan tidur pertama, yaitu tidur ringan, tubuh, mental, dan pikiran Anda berada di ambang realita dan bawah sadar setengah sadar, setengah (hampir) tertidur. Otak menghasilkan apa yang dikenal sebagai gelombang beta yang kecil dan cepat. Mata tertutup, namun masih dapat dibangunkan atau terbangun dengan mudah. Pergerakan mata di tahap ini sangat lambat, begitu pula dengan aktivitas otot. Dalam hal ini kebutuhan yang sesuai dengan penerapan teori keperawatan yang diberikan keluarga adalah teori kebutuhan dasar Virginia Henderson yaitu kebutuhan istirahat dan tidur.

m. Pemenuhan kebutuhan bekerja

Partisipan mengungkapkan dikarenakan klien cuti bekerja dimana sedang menjalani pengobatan kemoterapi keluarga masih memberikan kesempatan kepada klien untuk melakukan pekerjaan rumah agar klien merasa percaya diri bahwa masih dipercaya dalam melakukan perkerjaan 
dirumah sebagai penghargaan untuk dirinya sendiri.

Kebutuhan bekerja lebih ditekankan bagaimana kebutuhan pasien dalam berprestasi. Berdasarkan teori Abraham Maslow Setiap individu memiliki kebutuhan atau keinginan evaluasi diri yang stabil terhadap harga diri baik itu harga diri sendiri maupan terhadap orang lain. Pada tingkat ini merupakan kebutuhan harga diri yang kemudian dapat diklasifikasikan menjadi dua yang pertama keinginan akan kekuatan, prestasi dan kecukupan, penguasaan, kompetensi dan kepercayaan diri. Kedua reputasi, rasa hormat atau penghargaan dari orang lain, status, pengakuan, perhatian, martabat dan penghargaan.

n. Pemenuhan kebutuhan rekreasi

Keluarga tetap memberikan pemenuhan kebutuhan rekreasi seperti mengajak klien makan diluar rumah, mengunjungi keluarga, mengajak klien jalan-jalan serta menghibur klien yang bertujuan untuk mengurangi rasa stres klien.Hiburan atau rekreasi merupakan salah satu kebutuhan sekunder dan ikut berperan dalam pembentukan kepribadian manusia, saat individu melakukan kegitan hiburan maka akan mendapatkan kepuasan dan kesenangan dan memberikan keseimbangan dalam pertumbuhan dan kreativitas, kompetensi dan watak, selain itu dapat meningkatkan pengetahuan dan kondisi fisik yang rileks, stabilits emosi yang terkontrol, dan hubungan sosial. Kegiatan rekreasi dilakukan berdasarkan kebutuhan dan minat seseorang yang terdiri dari beberapa kegiatan yang meliputi rekreasi kesehatan, rohani dan pendidikan. Manfaat kegiatan rekreasi dilakukan oleh individu diantaranya meningkatkan relaksasi, dapat mengembangkan keterampilan dan kemampuan pribadi dan perasaan terhibur (Rodriguez-Mateos et al., 2019).

\section{Kesimpulan}

Pengalaman keluarga dalam merawat pasien dengan diagnosa kanker adalah pengalaman yang berarti bagi keluarga karena dari beberapa keluarga yang pernah merawat pasien kanker di rumah merasa bahwa keluarga masih mampu mendampingi klien bila merasa butuh bantuan, membantu memenuhi kebutuhan dasar sehari-hari klien serta ikut dalam melakukan pelaksanaan perawatan luka yang mana masih jarang ada keluarga yang mampu melakukan.

Adapun pengalaman keluar ketika merawat pasien kanker mereka menyatakan bahwa dirinya senang ikut serta dalam melakukan perawatan bahkan ada keluarga yang selalu ikhlas dalam melakukan perawatan tetapi juga ada partisipan yang mengungkapkan bahwa dirinya merasa kahwatir selama melakukan perawatan karena takut terjadi hal yang tidak diinginkan. Beberapa partisipan juga merasa harus berusaha dalam memberikan perawatan agar klien merasa nyaman dilingkungan rumah agar dapat mengurangi stres.

Pengalaman selanjutnya adalah pengalaman yang didapat setelah melakukan perawatan dalam merawat pasien kanker keluarga mendapatkan pengalaman yaitu mampu membantu dalam perawatan luka serta meningkatkan sikap caring terhadap klien. Keluarga jua mendapatkan manfaat seperti lebih siap dalam mencegah terjadinya risiko kanker pada keluarga yang sehat serta partisipan yang lain juga merasa bahwa kesabaran dalam melakukan perawatan meningkat.

\section{BIBLIOGRAFI}


Aini, N. (2016). Satiningsih.(2015). Ketahanan Psikologi Pada Perempuan Penderita Kanker Payudara.

Albrecht, T. A., \& Taylor, A. G. (2012). Physical Activity In Patients With Advanced-Stage Cancer: A Systematic Review Of The Literature. Clinical Journal Of Oncology Nursing, 16(3), 293.

Alligood, M. R. (2014). Areas For Further Development Of Theory-Based Nursing Practice. Mr Alligood (Ed.), Nursing Theory: Utilization \& Application, 414424.

Anggraeni, R., \& Indrarti, A. (2010). Klasifikasi Status Gizi Balita Berdasarkan Indeks Antropometri $(\mathrm{Bb} / \mathrm{U})$ Menggunakan Jaringan Saraf Tiruan. Universitas Gunadarma.

Aviyah, E., \& Farid, M. (2014). Religiusitas, Kontrol Diri Dan Kenakalan Remaja. Persona: Jurnal Psikologi Indonesia, $3(02)$.

Barofsky, I. (2012). Can Quality Or QualityOf-Life Be Defined? Quality Of Life Research, 21(4), 625-631.

Bisaro, B., Montani, M., Konstantinidou, G., Marchini, C., Pietrella, L., Iezzi, M., Galiè, M., Orso, F., Camporeale, A., \& Colombo, S. M. (2012). P130cas/Cyclooxygenase-2 Axis In The Control Of Mesenchymal Plasticity Of Breast Cancer Cells. Breast Cancer Research, 14(5), 1-12.

Black, J. M., \& Hawks, J. H. (2014). Keperawatan Medikal Bedah; Manajemen Klinis Untuk Hasil Yang Diharapkan.

Brewin, C. R. (2013). "I Wouldn't Start From Here"-An Alternative Perspective On Ptsd From The Icd - 11: Comment On Friedman (2013). Journal Of Traumatic Stress, 26(5), 557-559.
Caesandri, S. D. P., \& Adiningsih, S. (2015). Peranan Dukungan Pendamping Dan Kebiasaan Makan Pasien Kanker Selama Menjalani Terapi. Media Gizi Indonesia, 10(2), 157-165.

Cao-Lormeau, V.-M., Blake, A., Mons, S., Lastère, S., Roche, C., Vanhomwegen, J., Dub, T., Baudouin, L., Teissier, A., \& Larre, P. (2016). Guillain-Barré Syndrome Outbreak Associated With Zika Virus Infection In French Polynesia: A Case-Control Study. The Lancet, 387(10027), 1531-1539.

Dwijayanti, D. R., \& Rifa'i, M. (2015). Gynura Procumbens Ethanolic Extract Promotes Lymphocyte Activation And Regulatory T Cell Generation In Vitro. Journal Of Tropical Life Science, 5(1), 14-19.

Ekström, M., Currow, D. C., \& Moens, K. (2016). Symptom Patterns In Populations. Palliative Care In Respiratory Disease (Ers Monograph), 70-84.

Ferrell, B., \& Coyle, N. (2006). Textbook Of Palliative Nursing. Oxford University Press, Usa.

Friedman, J., Hastie, T., \& Tibshirani, R. (2010). Regularization Paths For Generalized Linear Models Via Coordinate Descent. Journal Of Statistical Software, 33(1), 1.

Galway, K., Black, A., Cantwell, M., Cardwell, C. R., Mills, M., \& Donnelly, M. (2012). Psychosocial Interventions To Improve Quality Of Life And Emotional Wellbeing For Recently Diagnosed Cancer Patients. Cochrane Database Of Systematic Reviews, 11.

Gitarja, W. S. (2007). Penatalaksanaan Perawatan Luka Kanker. Indonesian Journal Of Cancer, 1(3).

Henriksson, A., \& Årestedt, K. (2013). 
Exploring Factors And Caregiver Outcomes Associated With Feelings Of Preparedness For Caregiving In Family Caregivers In Palliative Care: A Correlational, Cross-Sectional Study. Palliative Medicine, 27(7), 639-646.

Huda, C., Putri, A. E., \& Sari, D. W. (2019). Uji Aktivitas Antibakteri Fraksi Dari Maserat Zibethinus Folium Terhadap Escherichia Coli. Jurnal Sainhealth, 3(1), 7-14.

Janitra, F. E., Wijayanti, K., Wahyuningsih, I. S., \& Apriyanti, H. W. (2019). Peningkatan Kualitas Hidup Pasien Kanker Payudara Melalui Program Bestcare (Breast Cancer Wound And Palliative Care). Jurnal Inovasi Hasil Pengabdian Masyarakat (Jipemas), 3(1), 46-53.

Knaul, F. M., Langer, A., Atun, R., Rodin, D., Frenk, J., \& Bonita, R. (2016). Rethinking Maternal Health. The Lancet Global Health, 4(4), E227-E228.

Kolcaba, K., Dowd, T., Steiner, R., \& Mitzel, A. (2004). Efficacy Of Hand Massage For Enhancing The Comfort Of Hospice Patients. Journal of Hospice \& Palliative Nursing, 6(2), 91-102.

Koloski, N. A., Jones, M., Kalantar, J., Weltman, M., Zaguirre, J., \& Talley, N. J. (2012). The Brain-Gut Pathway In Functional Gastrointestinal Disorders Is Bidirectional: A 12-Year Prospective Population-Based Study. Gut, 61(9), 1284-1290.

Larsen, P., Nielsen, J. L., Dueholm, M. S., Wetzel, R., Otzen, D., \& Nielsen, P. H. (2007). Amyloid Adhesins Are Abundant In Natural Biofilms. Environmental Microbiology, 9(12), 3077-3090.

Mccloskey, G., Perkins, L. A., \& Van Diviner, B. (2008). Assessment And Intervention For Executive Function Difficulties. Taylor \& Francis.
Mu'afiro, A., Suwito, J., Waluyo, K. O., \& Christiany, I. (2019). Self Care Management Client Dm Type 2 In Tambakrejo Community Health Center, Surabaya. Indian Journal of Forensic Medicine \& Toxicology, 13(4).

Noviarini, N. A., Dewi, M. P., \& Prabowo, H. (2013). Hubungan Antara Dukungan Sosial Dengan Kualitas Hidup Pada Pecandu Narkoba Yang Sedang Menjalani Rehabilitasi. Prosiding Pesat, 5.

Ongge, O. (2015). The Dynamics Of Indonesia-Malaysia Bilateral Relations Since Independence: Its Impact On Bilateral And Regional Stability. Asian Conference On Asian Studies.

Pegado, C. M. A., Andrade, L. A. De, Félix, L. P., \& Pereira, I. M. (2006). Efeitos Da Invasão Biológica De Algaroba: Prosopis Juliflora (Sw.) Dc. Sobre A Composição E A Estrutura Do Estrato Arbustivo-Arbóreo Da Caatinga No Município De Monteiro, Pb, Brasil. Acta Botanica Brasilica, 20(4), 887-898.

Perry, E. M., \& Potter, J. M. (2006). Materiality And Social Change In The. Feminist Anthropology: Past, Present, And Future, 115.

Purnawan, C., Martini, T., \& Afidah, S. (2014). Penurunan Kadar Protein Limbah Cair Tahu Dengan Pemanfaatan Karbon Bagasse Teraktivasi (Protein Reduction Of Tofu Wastewater Using Activated Carbon Bagasse). Jurnal Manusia Dan Lingkungan, 21(2), 143148.

Raisch, D. W., Campbell, H. M., Garnand, D. A., Jones, M. A., Sather, M. R., Naik, R., \& Ling, W. (2012). Health-Related Quality Of Life Changes Associated With Buprenorphine Treatment For Opioid Dependence. Quality Of Life Research, 21(7), 1177-1183. 
Roberts, A. W., Seymour, J. F., Brown, J. R., Wierda, W. G., Kipps, T. J., Khaw, S. L., Carney, D. A., He, S. Z., Huang, D. C. S., \& Xiong, H. (2012). Substantial Susceptibility Of Chronic Lymphocytic Leukemia To Bcl2 Inhibition: Results Of A Phase I Study Of Navitoclax In Patients With Relapsed Or Refractory Disease. Journal Of Clinical Oncology, 30(5), 488.

Rodriguez-Mateos, A., Istas, G., Boschek, L., Feliciano, R. P., Mills, C. E., Boby, C., Gomez-Alonso, S., Milenkovic, D., \& Heiss, C. (2019). Circulating Anthocyanin Metabolites Mediate Vascular Benefits Of Blueberries: Insights From Randomized Controlled Trials, Metabolomics, And Nutrigenomics. The Journals of Gerontology: Series A, 74(7), 967-976.

Saragih, B. (2018). Agribisnis: Paradigma Baru Pembangunan Ekonomi Berbasis Pertanian. Pt Penerbit Ipb Press.

Saxton, J., \& Daley, A. (2010). Exercise And Cancer Survivorship. Springer.

Setiawan, A. R. (2019). Penyusunan Program Pembelajaran Biologi Berorientasi Literasi Saintifik. Seminar Nasional Sains \& Entrepreneurship, 1(1).

Sudiharto, D. W. (2007). Implementasi Ltsp (Linux Terminal Server) Sebagai Solusi
Optimalisasi Penyelenggaraan Infrastruktur Laboratorium Komputer Di Perguruan Tinggi (Studi Kasus: Laboratorium Tuk (Tempat Uji Kompetensi), Teknik Informatika, Stt Telkom). Seminar Nasional Aplikasi Teknologi Informasi (Snati).

Sumiati, S. (2017). Penggunaan Leaflet Terhadap Peningkatan Pengetahuan Dan Sikap Keluarga Baru. Jurnal Media Kesehatan, 10(1), 52-57.

Ullrich, S., \& Nitsche, C. (2020). The SarsCov-2 Main Protease As Drug Target. Bioorganic \& Medicinal Chemistry Letters, 127377.

Watson, S. K., Reamer, L. A., Mareno, M. C., Vale, G., Harrison, R. A., Lambeth, S. P., Schapiro, S. J., \& Whiten, A. (2017). Socially Transmitted Diffusion Of A Novel Behavior From Subordinate Chimpanzees. American Journal of Primatology, 79(6), E22642. 